\title{
From the Trenches
}

This section is intended for occasional contributions from on-the-ground practitioners. Our hope is that the definition of this category of paper will inspire practitioners to submit notes and articles - typically in the range of 2,000 to 10,000 words - to the World Trade Review. As with all notes and articles submitted to the World Trade Review, manuscripts in this category have been reviewed by independent referees. However, the focus is intended to be practice oriented and at least one of the two referees was a fellow practitioner.

\section{The AGOA Extension and Enhancement Act of 2015, the SA-US AGOA negotiations and the Future of AGOA}

\author{
FAIZEL ISMAIL * \\ University of Cape Town, South Africa
}

\begin{abstract}
The African Growth and Opportunity Act (AGOA) is a non-reciprocal preferential trade programme that the US offers to 49 sub-Saharan African countries. President Obama's decision to extend AGOA, which was set to expire at the end of September 2015, for another ten years (2015 to 2025), was highly controversial. The Extension and Enhancement of AGOA Act, signed into law by President Obama, on the 29 June 2015, had thus included many new provisions to incorporate the views of the US Congress on the implementation of the tenyear extension and the future trajectory of AGOA. In this paper, the new Extension and Enhancement of AGOA Act is analysed to elucidate the new and additional powers that the new AGOA Act provides the US Congress, the US Administration, and US business lobbies, and the implications of these changes for sub-Saharan African countries. At least three new trends in the 2015 AGOA Act can be identified: payment for preferences, institutional attrition, and a shift to reciprocity. These trends, it is argued in this paper, are potentially contrary to a more mutually beneficial relationship between the US and Africa. The paper offers some reflections on the future of AGOA.
\end{abstract}

*Email: faizel.ismail51@gmail.com. 


\section{Introduction}

The African Growth and Opportunity Act (AGOA) is a non-reciprocal preferential trade programme that the US offers to 49 sub-Saharan African countries (Williams, 2015). When it was first signed into law, on the 18 May 2000, President Clinton's initiative was a major policy shift for the United States, which until then mainly used its Aid programme to support poor African economies (Schneidman and Lewis, 2012). The US Congress adopted a bipartisan approach to AGOA, extending AGOA on three occasions under the Presidency of George W. Bush (Schneidman and Lewis, 2012). President Obama's decision to extend AGOA, which was set to expire at the end of September 2015 for another ten years (2015 to 2025), is a reflection of the continuity in US policy towards Africa since the beginning of the new millenium. The United States Trade Representative, Ambassador Michael Froman, in his motivation for the extension of AGOA to the US Congress, in early 2015, confirmed this approach when he stated that 'AGOA has been the cornerstone of America's economic engagement with subSaharan Africa over the past fourteen years' (Williams, 2015).

The debate on the extension of AGOA in the US Congress, however, was highly controversial. Some Congressional leaders argued that it was time to change AGOA from its original offer of unilateral benefits to sub-Saharan African countries, towards one of full reciprocity. Others argued that AGOA should only be extended for a short period of time, of between three and five years. The experience of the EU with African countries was very instructive for many in Washington. These observers argued that the EU was in an advanced stage of transitioning its unilateral trade preference programme, the Cotonou Agreement, into bilateral free trade agreements - the so-called EU-ACP Economic Partnership Agreements (EPAs) - and that the United States should follow this new trend in EU trade policy (Schneidman, 2015). However, African countries had lobbied hard in Washington for the extension of AGOA, arguing that their economies were still at an early stage of development and that demanding reciprocity would be premature.

In the case of South Africa, which had been a beneficiary of AGOA since 2000, there was a strong view in the US Congress that South Africa was too large and developed an economy to continue to receive unilateral preferences from the US, and that it should be graduated out of AGOA, at the end of September 2015. In addition, there was a very powerful business lobby in the US poultry industry that had a particular grievance against South Africa for imposing an antidumping action against US exports of bone-in-chicken pieces to South Africa, since 2000, thus effectively blocking its exports (Pigman, 2016). Two US Senators, Chris Coons and Johnny Isakson, made it very clear that they would block the passage of any extension of AGOA and the inclusion of South Africa, in particular, if the flow of US chicken legs into South Africa was not resumed. The Extension and Enhancement of AGOA Act, signed into law by President 
Obama, on the 29 June 2015, had thus included many new provisions to incorporate the views of the US Congress on the implementation of the 10-year extension and the future trajectory of AGOA.

In this paper, the new Extension and Enhancement of AGOA Act is analysed to elucidate the new and additional powers that the new AGOA Act provides the US Congress, the US Administration, and US business lobbies, and the implications of these changes for sub-Saharan African countries. The critique offered in this paper of the new AGOA is not meant to undervalue the very significant benefits that AGOA provides to sub-Saharan Africa countries, including South Africa. It should be acknowledged that the extension of AGOA for a ten-year period is a significant achievement for both African negotiators and advocates for AGOA in Washington. The purpose of this paper is to point to the potential dangers of increased attrition that could arise from these new 'flexibilities' or 'conditions' of the new AGOA. The discussion proceeds as follows: First, the existing provisions of AGOA are discussed and the utilization of AGOA benefits by African countries are briefly analysed. A brief assessment of the actual benefits of AGOA for the rest of sub-Saharan Africa (excluding South Africa) is undertaken. Second, AGOA's conditionality provisions are briefly discussed and the new conditions in the 2015 AGOA legislation are assessed. Third, the SA-US negotiations are briefly discussed to illustrate the use of the new provisions of AGOA and draw some lessons for the rest of sub-Saharan Africa. Fourth, the paper discusses the new trends in the 2015 AGOA legislation. At least three new trends in the 2015 AGOA Act can be identified: payment for preferences, institutional attrition, and a shift to reciprocity. These trends, it is agued in this paper, are potentially contrary to the interests of Sub-Saharan Africa and a more mutually beneficial relationship between the US and Africa. Finally, the paper concludes with some reflections on the future trajectory of AGOA and recommendations for sub-Saharan Africa in their future trade relations with the US.

\section{An Assessment of AGOA's benefits and utilization by sub-Saharan African countries?}

The African Growth and Opportunity Act (AGOA), is a preferential programme for about 6800 tariff lines including those provided by Generalized System of Preference (GSP), that the US offers to 49 sub-Saharan African countries (with the inclusion of South Sudan from 2012). After President Bill Clinton signed AGOA into law on the 18 May 2000, the legislation was extended and re-authorized on four occasions (2004, 2006, 2007, and 20012) (Meltzer, 2015). When AGOA was first passed, its benefits were set to expire after eight years and it was subsequently extended for another seven years. The last iteration of AGOA was scheduled to expire at the end of September 2015 (Schneidman and Lewis, 2012). President Obama signed the ten-year extension of AGOA (2015 to 2025) into law on the 29 June 2015. AGOA, together with GSP granted AGOA beneficiaries 
duty-free access to roughly $86 \%$ of US products (Williams, 2015). The excluded products tend to be mainly agriculture products and thus only $3 \%$ of total exports of AGOA beneficiaries were agriculture products (Meltzer, 2015). Ineligible products currently include certain steel products, canned apricots and peaches, dried garlic, frozen fruit, and some leather and glass products (Williams, 2015).

However, at its inception in 2000 AGOA did extend duty-free treatment to certain apparel and footwear products, which were not eligible under GSP (even for LDCs) (Williams, 2015). The textile and apparel preferences enjoyed by subSaharan African countries are relatively generous as the normal or mfn (mostfavoured-nation) average US tariff for apparel is $11.4 \%$ (Pigman, 2016). In addition, AGOA has relatively liberal rules of origin that support the creation of regional supply chains in sub-Saharan Africa and flexibility for LDCs (Pigman, 2016). To qualify to enter the US market under AGOA duty free preferences, textile and apparel must be made in the beneficiary country and could include yarn and fabric from the US and sub-Saharan Africa. AGOA also allows for 'regional cumulation' whereby multiple AGOA beneficiaries can contribute towards a product's required 35\% regional value content and the United States can contribute $15 \%$ of the $35 \%$ (Williams, 2015). AGOA also has more flexible rules of origin for Least Developed Countries (LDCs). The third-country fabric rule that applies to LDCs allows for a certain quantity of AGOA apparel exports to be produced from yarns and fabrics of any origin. AGOA defines LDCs as countries with a per capita gross national product (GNP) of less than $\$ 1,500$ in 1998, as measured by the World Bank. Botswana, Namibia, and Mauritius are also explicitly granted LDC status in AGOA, despite reflecting GNP per capita levels above that threshold (Williams, 2015).

To be eligible for trade preferences under the textile and apparel provisions, AGOA beneficiary countries must have in place an effective visa system to prevent unlawful transshipments and the use of counterfeit documents, as well as effective enforcement and verification procedures, and be separately designated to receive this tariff treatment. In 2013, only 27 AGOA beneficiary countries also qualified for the general textile and apparel provisions of AGOA (Williams, 2015). These AGOA preferences for textiles and apparel have been extended, with AGOA, to 2025 (Pigman, 2016). However, for non-LDC apparel producers, such as South Africa, a much more restrictive 'yarn-forward' rule of origin applies, that is, both yarn and fabric must be made either in an AGOA beneficiary or in the USA for the finished garment to qualify (Pigman, 2016).

\section{How have African countries benefitted from AGOA?}

While some African countries have been able to use AGOA preferences to attract foreign investment and increase their production and exports of mainly clothing and textiles, most African countries have not been as successful. This is illustrated by the recent data on US-Africa trade discussed below. 
If one excluded the oil exporters (Nigeria, Angola, Chad, Gabon, Congo, and Ivory Coast) South Africa was the largest exporter to the US in 2013 with its exports amounting to $\$ 8.1$ billion, and of this $\$ 3.1$ billion of it falling under AGOA including GSP. Only seven other sub-Saharan countries exported more than $\$ 100$ million to the US. These include: Kenya $(\$ 424)$, Lesotho $(\$ 350$ million), Ghana (\$305 million), Mauritius (\$280 million), Namibia (\$261 million), Ethiopia (\$192 million), and Cameroon (\$130 million). Although these countries (mainly Kenya, Lesotho, and Mauritius) have succeeded in using AGOA to expand their clothing and textile exports to the US, AGOA beneficiaries still represent less than $1 \%$ of total US imports of apparel. The US Congressional Research Service states that: 'US apparel imports totaled $\$ 82.7$ billion in 2014, with $\$ 30.7$ billion from China, $\$ 9.2$ billion from Vietnam, and less than $\$ 1$ billion total from AGOA beneficiaries' (Williams, 2015). The same study states that: 'US preferential imports were less than $\$ 1$ million for over half of the 40 AGOA beneficiary countries in 2014' (Williams, 2015). However, a handful of countries have made strong use of the preference programme and have increased employment in economic sectors that benefited from duty-free treatment under AGOA. For example, the government of Lesotho, one of the major apparel exporters under AGOA, estimates that employment in manufacturing rose from 19,000 in 1999 to 45,700 in June 2011 (Williams, 2015).

For the United States, its AGOA imports from sub-Saharan African countries are relatively insignificant with no real negative impact on its own production and employment. In 2014, the share of AGOA exports in total US imports was a mere $1 \%$ (a drop from $2 \%$ in 2013). There was a dramatic drop in oil exports from the continent to the US, since 2013. Even the largest volume of manufactured products exported to the US, such as motor vehicles, occupied only $0.39 \%$ of the US market for autos. In the case of fruit, this was $0.02 \%$, and in the case of meat and fish, the figure was $0.01 \%$.

In response to the demands by African countries to support their efforts to build their capacity to export to the United States, the US Agency for International Development (USAID) and the Millenium Challenge Fund (MCC) provide funding for trade related capacity building to support AGOA. In 2011, the US Administration created the African Competitiveness and Trade Expansion (ACTE) initiative with an annual budget of $\$ 30$ million. Three African Trade Hubs were created by the ACTE initiative, in Ghana, Kenya, and Botswana to support capacity building and exports of AGOA beneficiaries into the United States (Williams, 2015).

\section{AGOA's 'conditionalities' and the 'AGOA Extension and Enhancement Act of 2015,}

The legislation that contains the AGOA amendments also provides for several other areas of US preferential trade, including the Generalized System of 
Preferences (GSP), and is thus titled as the 'Trade Preferences Extension Act of 2015' (US Congress, 2015). The subsection of this Act makes provision for the extension of AGOA and is titled: 'AGOA Extension and Enhancement Act of 2015'. To avoid confusion and maintain the focus of the discussion on AGOA, the latter title of the legislation shall be referred to in the discussion that follows.

\section{The AGOA 'conditionalities'}

The original AGOA legislation indicated that a country's eligibility for AGOA depends on three major requirements: (1) having established, or are currently making progress toward, a market-based economy, the rule of law, the elimination of trade barriers, economic policies that reduce poverty, systems to combat corruption, and protection of workers' rights; (2) not engaging in activities that undermine US national security; and (3) not engaging in gross violations of human rights or support for terrorism. For a country to become an AGOA beneficiary, the president must determine that the country fits these criteria (Schneidman and Lewis, 2012).

In 2013, about 39 sub-Saharan countries, including South Africa, were beneficiaries of AGOA (USITC, 2014). AGOA defines 'sub-Saharan Africa' to refer to 49 SSA countries, including South Sudan, added in 2012 (USITC, 2014). In his initial proclamation on 2 October 2000, after AGOA was enacted, President Clinton designated 34 SSA countries as AGOA-eligible countries. The President is required to monitor, review, and report to Congress annually on the progress of each of the 49 countries in meeting the AGOA eligibility requirements in order to determine the current or potential eligibility of each country to be designated as a beneficiary (USITC, 2014). In June 2014, President Obama re-instated Madagascar and terminated AGOA eligibility for Swaziland 'due to issues with worker rights', with effect from the 1 January 2015. Swaziland was the fifth largest non-energy exporter under AGOA in 2014. In December 2014, President Obama reinstated benefits for Guinea-Bissau and terminated benefits for South Sudan and The Gambia, due to 'issues with human Rights' (Williams, 2015).

AGOA provides for the creation of a US-sub-Saharan Africa Trade and Economic Cooperation Forum that meets annually to 'discuss expanding trade and investment relations between the United States and sub-Saharan Africa and the implementation of AGOA' (Williams, 2015). The Forum includes meetings held at Ministerial and senior official levels, as well as with civil society representatives and the business community. The 14th AGOA Forum took place in Libreville, Gabon on 24-27 August 2015. We proceed, in the discussion below, to evaluate the changes made to the AGOA legislation focusing on the 'flexibilities' or 'conditions' required of African countries and the new powers provided to the US Congress and Administration in this regard. It is argued that while these 'flexibilities' are not new, they can become 'new conditions' depending on how they are implemented. 
The AGOA Extension and Enhancement Act of 2015

In addition to providing for the extension of AGOA benefits for another ten years, from 2015 to 2025, the new AGOA Extension and Enhancement Act of 2015, also provides for some modifications to the rules of origin; some procedural changes, including a special 30-day out-of-cycle review for South Africa; support for capacity building; negotiations with beneficiary countries on trade and investment; a biennial review of US trade and investment relations with beneficiary countries; and a report to the US Congress one year after its enactment and every five years thereafter on the status of FTA negotiations with beneficiary countries (Williams, 2015).

The discussion below selectively discusses the above 2015 changes to the AGOA legislation. The discussion focuses on the provisions for opening markets: withdrawal, suspension, and termination of benefits; out-of-cycle reviews and reciprocity and FTA's.

A summary of the key provisions of the 'AGOA Extension and Enhancement Act of 2015 ,

\section{Opening markets}

Section 103 of the US Trade and Development Act of 2000 had already built in some key policy statements on eligibility requirements for sub-Saharan countries, including movement towards 'a market based economy that protects private property rights' (section 104) and 'the elimination of barriers to US trade and investment'. The 2000 Act also foreshadowed what was to be increasingly emphasized in the 2015 Act, that is the objective of the US 'to negotiate reciprocal trade agreements' (section 103) with African countries (US Congress, 2015).

However, the 2015 AGOA Act extends the objectives of AGOA to 'the elimination of barriers to trade and investment in sub-Saharan Africa, including high tariffs, forced localization requirements, restrictions on investment, and customs barriers'(section 102). It also calls for the implementation of the Agreement on Trade Facilitation of the WTO (section 102 (7)) (US Congress, 2015).

\section{Withdrawal, suspension and termination}

The Act goes on to provide for the 'withdrawal, suspension or limitation of preferential tariff treatment' to ensure 'compliance by the country' with US objectives on trade and investment in addition to 'termination' of eligibility that was already provided for in the 2000 Act. This provision was used by President Obama in the case of South Africa and is discussed below in the context of the SA-US AGOA negotiation. The 2015 AGOA Act also provides for the private sector or 'any interested person, at any time' to file a petition with respect to the failure of 'compliance' of a country, 'with eligibility requirements' and to petition the USTR in this regard (US Congress, 2015). 


\section{Out-of-cycle reviews}

The 2015 AGOA Act provides that the President may 'at any time, initiate an outof-cycle review of whether a beneficiary country is making continual progress in meeting the requirements', for eligibility of AGOA. The Act also provides that if the President determines that a country does not meet the requirements ... the President shall ... 'terminate the designation of the country as a beneficiary subSaharan African country or withdraw, suspend, or limit the application of dutyfree treatment'. In this context, what is of particular concern for South Africa is that the Act makes specific reference to South Africa, in the section titled: 'Sense of Congress' (subsection $3(\mathrm{E})$ ). This section states, that 'recognizing that some concerns have been raised about compliance ... of some beneficiary countries ... the President should initiate an out-of-cycle review ... with respect to South Africa ... not later than 30 days after the date of enactment of this subsection'. The use of this provision in the case of South Africa will be further discussed in the section below. The Act further provides for continuous reviews on whether individual sub-Saharan African countries are meeting the eligibility criteria of the Act, one year after its enactment, and biennially thereafter.

\section{Reciprocity and FTAs}

Another important element of the 2015 Act, which builds substantially upon the provision already contained in the 2000 Act, is the principle of reciprocity. The 2015 Act states that it is the policy of the United States to: 'seek to deepen and expand trade and investment ties between sub-Saharan Africa and the United States' by, amongst other things, negotiating 'agreements with individual sub-Saharan countries ... as well as Regional Economic Communities' and promoting 'full implementation of commitments made under the WTO Agreement'. In this regard, the Act follows the EUEPAs that deter their negotiating partners from providing better trade access to third countries, by stating that the policy of the US is to 'promote the negotiation of trade agreements that cover substantially all trade between parties to such agreements and, if other countries seek to negotiate trade agreements that do not cover substantially all trade, continue to object in all appropriate forums'. The 2015 Act provides that 'not later than 1 year after the enactment of this Act' the USTR shall provide a report that 'identifies sub-Saharan African countries that have expressed an interest in entering into a free trade agreement with the United States'. It further states that the report shall evaluate 'the viability and progress (of such countries) ... towards entering into free trade agreements' and 'describes a plan for negotiating and concluding such agreements’ (US Congress, 2015).

\section{The SA-US AGOA negotiations}

South Africa is the most significant non-fuel beneficiary of AGOA. South Africa's AGOA (including GSP) exports amounted to US\$3.1 billion in 2014, down from 
US\$3.6 billion in 2013. Of total SA exports to the USA, 38\% went under AGOA (including GSP) in 2014, down from 44\% in 2013. Of all the AGOA beneficiaries, South Africa also has the most diversified exports of AGOA non-fuel products into the US market, helping to expand its exports in significant high value growth sectors of the South African economy, such as automobiles, chemicals, and agriculture products (citrus, macadamia nuts, wine, etc,) (Williams, 2015).

Although President Obama promised to 'enhance and extend AGOA' at the US-Africa Summit, held in Washington in 2014, the issue of the continuing dispute between the two poultry industries cast a shadow on South Africa's future inclusion in AGOA. Two US Senators (Chris Coons and Johnny Isakson), representing the States of Delaware (the home of the USAPEEC) and Georgia (one of the largest Chicken producing States in the US), threatened to block the extension of AGOA and/or the inclusion of South Africa in AGOA if the dispute on the AD was not resolved to the satisfaction of the US poultry industry. South Africa had imposed anti-dumping duties on US bone-in-chicken pieces in 2000. While the US poultry associations regarded the South African imposed AD duties as unfair, they did not use the WTO dispute settlement route to resolve the dispute. Instead, they decided to use the upcoming negotiations in the US Congress, for the renewal of AGOA, to lobby the US Administration to use the opportunity as leverage to resolve the outstanding dispute (Business Day, 2015a). This prompted Minister Rob Davies, the minister of trade and industry of South Africa, to urge the South African poultry industry to meet with its counterparts in the US with a view to finding a mutually agreed compromise (Davies, 2015). The first meeting between the two poultry associations took place in September 2014 in Washington.

From the outset of the negotiation, it became evident that the US Senators were to use the AGOA extension as an opportunity to re-open the South African market for US bone-in chicken pieces. Senator Isakson admitted that, 'we have been trying to use the AGOA extension as a lever to get (the South Africans) to come to the table ... and come up with a quota that made sense for both' (Business Day, 2015a). However, the US began to increase the pressure on South Africa to find a solution to the chicken issue when 13 US Senators wrote to Minister Davies urging him to resolve the dispute 'urgently' (Business Report, 2015a). Senator Orin Hatch, the chairman of the Senate finance committee argued that the US Administration must make 'aggressive' use of tools in the updated African Growth and Opportunity Act (draft Bill) to pressure SA to comply with its conditions (Business Day, 2015c).

In the negotiation between the US and the South African poultry industries, several offers were exchanged but the gap remained significant until a negotiating meeting was held in Paris between the two industries led by the governments of the United States and South Africa. After a two-day meeting held in Paris, on the 4 and 5 June 2015, South African and US negotiators made a breakthrough in the longstanding dispute of the export of bone-in chicken pieces from the US to South 
Africa. Prior to the meeting in Paris, the US poultry industry demanded the creation of a quota for 140,000 tons of bone-in chicken pieces from the US, while the South African Poultry Association (SAPA) was only prepared to offer 30,000 tons per annum (t/a). Before the Paris meeting the US negotiators reduced their demand to $110,000 \mathrm{t} / \mathrm{a}$ and SAPAs offer stood at 50,000 t/a. The breakthrough in the negotiations was achieved when both sides agreed on a quota of 65,000 t/a. This agreement cleared the way for President Obama to include South Africa in the extension of AGOA.

When President Obama signed the bill to extend AGOA for another ten years, on the 29 June 2015, the inclusion of South Africa, however, had some new 'flexibilities' or 'conditions' attached. President Obama had included a special provision in the Act that specifically named South Africa (discussed above) and called for a '30-day out-of-cycle review' to be held on South Africa's eligibility. South Africa was required to satisfy the demands of all the US lobbies that had specific concerns with its trade and investment laws and policies, before it could fully qualify to remain in AGOA.

Thus, in accordance with this provision, the US Administration initiated an outof-cycle review on the eligibility of South Africa to receive benefits under AGOA and published a notice in the US Federal Register on the 21 July for a public hearing to be held on the 7 August 2015 (US Federal Register, 2015). The issues raised by the lobbies included their concerns with South Africa's animal health regulations on poultry, beef, and pork; policies on intellectual property rights; regulations on black economic empowerment; policies on investment and; draft private security bill. In addition to poultry (bone-in chicken pieces), the US demanded full market access for its beef and pork products. The USTR argued that some of its industry lobbies in the US believed that South Africa was 'discriminating' against the US as it was offering the EU (the main competitor of the US in South Africa) better market access due to the free trade agreement (the SA-EU Trade and Development Cooperation Agreement) that the EU enjoyed with South Africa. The US requested tariffs on a minimum of 387 products to be reduced to the level currently enjoyed by the EU as a result of the SA-EU TDCA and possibly the recently concluded EU-SADC EPA (Davies, 2016).

The National Pork Producers Council argued that, one of the criteria for consideration of whether to withdraw, suspend or limit eligibility is whether South Africa has made progress on 'the elimination of barriers to United States trade and investment'. In the view of the Pork Council, South Africa was maintaining high barriers against US pork and for this reason, it argued, South Africa's AGOA eligibility should be withdrawn. In the event that total withdrawal was not contemplated, the Pork Council further argued that its concessions should be limited substantially by removing products such as 'macadamia nuts, oranges, mandarins, citrus juice, ice cream, wine of fresh grapes, ethyl alcohol, motor vehicle bodies, mufflers and exhaust pipes' (US Federal Register, 2015). 
Although a great deal of debate on the long list of issues raised in the out-of-cycle review continued to be debated in the press, Minister Davies had managed to reach an agreement with Ambassador Froman to reduce the long list of demands to the 'three meats', poultry, beef, and pork, in a meeting with Minister Davies at the Gabon AGOA Forum held on the 25-27 August 2015. However, the pressure on South Africa to finalize the agreements on a range of animal health issues, including on poultry, beef, and pork, continued to mount, and the negotiations on these issues were to continue until well into early 2016. A more detailed discussion on each of the animal health issues is undertaken elsewhere. In this discussion, we analyse the use of the new 'conditionalities' of the AGOA 2015 Act in the SAUS AGOA negotiations.

On the 5 November 2015, while the vets from both sides were engaging on the animal health issues, President Obama informed the US Congress that he was to suspend South Africa's agricultural benefits if the outstanding issues on the three meats were not resolved by the 31 December 2015. Obama stated in the letter that 'South Africa was not making continuous progress toward the elimination of barriers to US trade and investment, as required by section 104 of AGOA' (Business Day, 2015b). Obama went on to state: 'I will continue to assess whether South Africa is making continual progress toward the elimination of barriers to United States trade and investment in accordance with AGOA eligibility requirements, as well as whether this suspension of benefits is effective in promoting compliance with those requirements.'

The 60-day deadline was unexpected by the South African negotiators. Minister Davies wrote in an oped in the Business Report that, "the reason the work has not been completed is due to the fact that both sides have had to engage on the documentation and negotiate the texts'. He went on to state that, 'It remains to be said that these are matters of animal health and have to be dealt with accordingly in a scientific and objective manner by the vets' (Business Report, 2015b). The South African and the US vets continued negotiating the detailed texts on animal health for poultry, beef, and pork during the December holiday period - missing the 31 December deadline set by President Obama's Proclamation of the 5 November 2015. However, by the 7 January 2016, three South African Ministers held a press conference to announce that the vets from both sides (the US and South Africa) had successfully concluded the detailed textual negotiations on all three meats - poultry, beef, and pork (Business Report, 2016). Minister Davies made a plea for the US to give South Africa a pass and lift the threat of suspension. He was quoted as saying: "we have concluded the work: that is a good sign. We are expecting and calling on the US to do the right thing, and for South Africa's continued involvement in AGOA without further interruptions' (Mail \& Guardian, 2016).

The USTR, Ambassador Froman, announced his satisfaction with the agreements in a press statement on the 7 January. However, he indicated that US stakeholders wanted to see their poultry on the shelves of retail stores in South Africa as a final benchmark. Thus, on the 11 January 2016 President Obama issued a 
Proclamation extending the deadline to suspend SA's agriculture concessions to the 15 March 2016. Again, the extension of the deadline and the moving of the goalposts was clearly a surprise for South African negotiators. The US had insisted that its exporters of poultry wanted to see their products on the South African retailors shelves to ensure that the system worked. This final hurdle was however again overcome by the 26 February when the first shipment of US poultry arrived at the Port of Durban. Minister Davies reported to the press as follows: 'Last Friday, the first shipment of American poultry (frozen chicken legs) arrived at the Port of Durban and was cleared by the port health authorities, thus allowing the products to be placed on South Africa's retail shelves before the deadline of March 15' (News Ghana, 2016).

Obama formally revoked the threat of suspension of South Africa's agriculture subsidies on 14 March 2016. The Proclamation stated that: 'I have determined that suspending the application of duty-free treatment to certain goods is no longer necessary to promote compliance by South Africa with such requirements.' In a brief press statement that accompanied the announcement, the US National Security Council spokesman, Nel Price, affirmed that: 'The United States and South Africa share a mutual interest in strong and equitable economic growth and opportunities for all our citizens. We look forward to continuing to work closely with South Africa to further enhance our trade and investment relationship' (Law360, 2016).

Almost two years of intense, technically complex, and politically tense negotiations had finally come to an end. However, as the ink began to dry on Obama's withdrawal of the threat of suspension, the USTR began to conduct consultations with African countries on the future of AGOA. The additions to the flexibilities or 'conditions' that have been added to the 2015 AGOA Act and the application of these new 'conditions' in the SA-US AGOA negotiations raise a number of questions about the new direction and trends in US trade policy towards Africa. These questions are discussed in the section below.

\section{New Trends in US approach to trade and investment with Africa?}

The 2015 AGOA Act raises at least three important policy questions. Is AGOA still a one-way preferential trade programme without costs? Does it still facilitate a cooperative trade and development relationship with the USA? For how long will the US still allow non-reciprocity in trade with sub-Saharan African countries? Three key trends or themes can be identified from a preliminary analysis of the 2015 AGOA Act. These new trends are briefly discussed here.

First, a one-way non-reciprocal arrangement that was to facilitate the increased integration of African countries into global markets has now become a programme that the US seeks to be paid for. AGOA preferences into the United States now has a price tag and can no longer be regarded as an act of solidarity or compensation for the ills of colonialism and the cold war or the high protectionism in Northern 
markets for the goods of export interest to African countries such as agriculture and textiles (Wilkinson, 2014). AGOA could also have been seen as a positive response to the negative impact of structural adjustment policies of the World Bank and the IMF in the 1980s that led to de-industrialization of many African countries (UNCTAD, 2006). The case of South Africa clearly illustrates that interest groups in the US (such as for poultry, beef, and pork products) have seen AGOA renewal as an opportunity to seek concessions (or reciprocity) in areas of interest to their sectors for a non-reciprocal US trade assistance programme (Business Day, 2015b).

Second, the 2015 Act creates a system of structural attrition between the United States and sub-Saharan African countries. It does this by leveraging a preferential tariff programme to gain increased access into sub-Saharan African markets. Further, the USTR is enabled by the new legislation to act in support of any lobby group in the US that seeks to advance their economic interests in such markets if these lobbies are aggrieved by some economic policy (trade or investment measures, such as IP or local content, environment, labour) of the country or trade agreement that the country has signed with a third country. Such an aggrieved party can petition the President to act against such a country by threatening to withdraw or suspend AGOA benefits or remove the country altogether from AGOA. This provision in the 2015 Act is likely to be utilized by specific vested US interests, and the USTR will be under pressure to carry out such threats (the US poultry industry has succeeded in applying such pressure on South Africa). Thus the new Act has built into the new AGOA a system of 'structural attrition' that threatens to create increased tension in US sub-Saharan African relations rather than deepening cooperation. African countries will no doubt have to consider the cost of this attrition and uncertainty on their trade and investment with the US, and many will look to the new emerging countries to support their development projects and programmes where the demands on reciprocity are not as sharp or aggressive. Thus, while the USTR has the 'right' to use these new powers vested in it by the new legislation, it will need to ensure that it uses these new 'flexibilities' granted it by the new Act in a prudent and sensitive manner, mindful of its potential consequences.

Thirdly, the initial good intention of AGOA, which was to provide a non-reciprocal tariff preference into the US market for sub-Saharan African countries that would stimulate investment in these countries for export-oriented industrialization, has turned into a tool to leverage increased market access into sub-Saharan African countries for US exports and investment. It should be remembered that historically, the United States has never been comfortable with the concept of preferences. It fought a hard battle with the UK to remove all preferences (unsuccessfully) during the formation of the GATT in 1947 and only reluctantly joined in the preferential game after enactment of the 1979 Enabling Clause (Kock, 1969; Toye and Toye, 2004). 
The 2015 Act is littered with references to 'reciprocity' (as discussed above). The Act underlines that the objective of the US is to take the first opportunity available to seek to negotiate reciprocal free trade agreements with sub-Saharan African countries. The US feels that it has a moral right to seek to advance its own trade and investment interests in Africa since, in its view, the EU has already negotiated and concluded several EPAs with individual countries and sub-regions in Africa. In the case of South Africa, the US has already begun the process of demanding to be treated in a similar manner as the EU, and has submitted South Africa with a list of 387 tariff lines where its companies believe that the playing field has been tilted in favour of the EU (Williams, 2015). South Africa has reduced (and is scheduled to further reduce) its tariffs vis-à-vis the EU based on commitments made in the TDCA (Trade and Cooperation Agreement) and SADC-EPA. The 2014 National Trade Estimates report of the US states that US exports face a disadvantage relative to EU goods in South Africa 'in a range of sectors including: cosmetics, plastics, textiles, trucks, agricultural exports and agricultural machinery' (Schneidman, 2015).

The US is also fearful that African countries may reduce their tariffs in bilateral agreements with the 'Emerging Markets', disadvantaging US companies. The 2015 Act thus calls on the USTR to oppose such arrangements. Clearly, the US has China in mind. Witney Schneidman points out that in 2009 China overtook the US as Africa's largest trading partner. He illustrates the Chinese threat to US business interests in Africa by stating that, in 2013, China-Africa trade was $\$ 210$ billion while the US figure for the same period was approximately $\$ 90$ billion (Schneidman, 2015).

The attitude of the US civil society commentators to these new 'flexibilities' or 'conditionalities' in the 2015 AGOA Act is best exemplified by veteran journalist Simon Barber, who argues that 'trade preferences such as AGOA are a unilateral gift and that the country giving them has great latitude in deciding what strings to attach' (Business Day, 2015d). Barber quotes David Thorne-a special advisor to US Secretary of State, John Kerry - who, reflecting on the debate with regard to South Africa and the 2015 AGOA process in the US Congress, stated: 'there is a clear sense that we need to look beyond AGOA to a more reciprocal and balanced relationship. SA has recently taken this step with Europe, and it is time for SA to move forward with the US.' Another trade expert on Africa, associated with the Brookings Institution in Washington, Witney Schneidman, offered the following advice to President Obama on US trade relations with Africa: 'the Obama administration should use the next two years to develop a new bipartisan and mutually beneficial framework for deepening commercial ties with Africa that is legally enforceable. A free trade agreement that takes into account the development challenges or "asymmetrical" realities that exists between the US and Africa would be a good place to start' (Schneidman, 2015).

Several provisions of the 2015 AGOA Act have made it clear that the US intends to transition the beneficiaries of AGOA out of its unilateral preferential arrangement towards reciprocal arrangements such as those being pursued by the EU in 
the EU-ACP Economic Partnerships Agreements (EPA). Early on in the negotiations on AGOA, an indication of the views of the US Congress was provided by US Senators, Jim Inhofe and Chris Coons, when they introduced the 'African Free Trade Initiative Act' as an amendment to the Trade Promotion Authority (TPA) Act (Inside US Trade, 19/05/2015). The Act would require the president 'to establish a plan to negotiate and enter into Free Trade Agreements (FTAs) in sub-Saharan Africa and would require the United States Trade Representative, the Millennium Challenge Corporation and USAID to coordinate and collaborate together on how to implement the goals established in the Free Trade Agreement plan' (ICTSD, 2015).

Senator Chris Coons went on to explain his views as follows:

I am hopeful that Congress will reauthorize AGOA for ten years, but during those ten years, the economies of sub-Saharan Africa should also develop trade relationships that can benefit both African and American businesses. Trade relationships done right can benefit everybody involved by creating good jobs, raising wages, and raising standards, and this bipartisan legislation will ensure that the Administration takes immediate steps to increase trade with Africa that is bilateral, duty-free, and beneficial for both countries. (Inside US Trade, 19/05/2015)

Ambassador Froman hinted at the direction of the future of AGOA during the 'Hearings' in the US Congress in January 2016 when he stated that Congress had asked the USTR to 'assess the prospects of putting us on a path to more permanent, reciprocal trade arrangements' (USTR, 2016).

The USTR, Ambassador Froman, was required to provide Congress with a list of sub-Saharan African countries that have expressed interest in negotiating a freetrade agreement with the United States, in terms of the new AGOA Act by June 292016 (Politico, 2016). As Froman was embarking on his visit to the Kigali World Economic Forum (WEF) meeting in May, 2016, the influential Washington online news service, Politico, also reminded its readers that 'the US embarked on free-trade talks with South Africa and other members of the Southern African Customs Union in 2003 but a deal was never reached' (Politico, 2016). The study by the Congressional Research Service on AGOA also refers to the SACU-US FTA negotiation that began in 20003 and was 'ultimately unsuccessful and postponed indefinitely in 2006' (Williams, 2015). The United States has however not given up on its ambition to negotiate free trade agreements with South Africa and the rest of sub-Saharan Africa. The 2015 AGOA Act compels it to explore the process once more. We proceed to make some concluding remarks on the discussion and make some recommendations on the way forward for Africa-US trade and investment relations. 


\section{Conclusions: Implications of the South African negotiation for Sub-Saharan Africa and the Future of $A G O A$}

AGOA is a unilateral preferential scheme that was created by President Clinton, at the beginning of the new millennium, to support the growth and development of sub-Saharan Africa. At the time of its creation, most African countries were suffering from low growth and high levels of unemployment and poverty. The front cover of The Econmist for May 2000 reflected the dire state of African economies at the time: 'Africa - the hopeless Continent' (Economist, 13/05/2000). South Africa had just emerged from its Apartheid past of racial inequality, high unemployment, and poverty. Clinton was keen to ensure that South Africa was provided with a helping hand to re-integrate into the world economy. Thus, since 2000 African economies have made very significant progress in growing their economies and reducing high poverty levels. From a continent described as 'hopeless' they rose to gain the new image described as 'Africa rising' (Deloitte \& Touche, 2013). While the implementation of AGOA has benefitted several African countries, the vast majority of subSaharan African countries have yet to utilize the opportunity that AGOA provides to grow and develop their economies (Williams, 2015). As the discussion above has indicated, some countries such as Lesotho, Mauritius, and Kenya have been able to to profit from the incentives it provides to new investors, to manufacture in Africa and export to the US, creating much needed productive capacity, jobs, and infrastructure in Africa.

AGOA has been the centerpiece of US trade and investment relations between the US and Africa since President Clinton initiated the creation of AGOA in 1998 and signed the first Act in 2000. Since then both President Bush and President Obama have acted consistently to deepen and strengthen AGOA. While there always were provisions in the AGOA Act since 2000 that also addressed the need for AGOA to support two-way trade and investment between the United States and Africa, the 2015 AGOA Act has created some new 'flexibilities' for the USTR that could be used as new 'conditions' that could undermine the original progressive objectives of the United States policy makers. This paper has argued that the new 'flexibilities', that could potentially be implemented as new 'conditions' in the 2015 AGOA Act have created three new trends in US trade relations with Africa: the right of US business lobbies to seek payment for preferential access by AGOA beneficiaries; a system of structural attrition in US-Africa trade relations, and a process of negotiations that seeks to transition AGOA beneficiaries to full reciprocity (or free trade) with the United States. The SA-US negotiations are instructive for the rest of sub-Saharan African countries as they serve as a case study for the future direction of US-Africa trade relations under AGOA. We have argued that these new trends in US-Africa relations could undermine the stated objectives of the United States since President Clinton began his initiative to grow African economies, strengthen African economic development, and reduce poverty. 
It is not the intention of this paper to undermine the value of the very significant trade benefits and opportunities for sub-Saharan African countries that are offered by the extension of AGOA for another ten years. On the contrary, this paper has argued that the extension of AGOA for a further ten years is a very positive outcome for both Africa and the supporters of AGOA in Washington. The purpose of this paper is to bring to the attention of US policy makers the enormous power the new AGOA Act has provided to the USTR and potentially to the US Congress and its business lobbies, and to urge the United States to ensure that the use of this power does not create unnecessary structural attrition in its trade and investment relations with sub-Saharan African countries. The challenge for the Unites States will be to avoid the use of these new 'flexibilities' as onerous new 'conditions' in the new AGOA. Instead, the United States should focus on deepening and strengthening the trade and investment relationship with Africa that supports its economic development agenda and regional integration. African countries will need to lobby the US to support the building of industrial capacity and infrastructure in Africa. Africa's own vision reflected in the African Union's Agenda 2063 and its trade integration programme, being pursued in the Continental Free Trade Area (CFTA) negotiations, will need to be advanced to enable the beneficiaries of AGOA to more effectively utilize the opportunities it provides to access the US market. African countries will also need to campaign in Washington for the current ten-year extension of AGOA preferences to be enhanced and fully implemented until 2025 - creating more certainty for investors in Africa that are keen to use the AGOA preferences to export into the US market.

\section{References}

Business Day (2015a), 'Chicken Dispute Unlikely to Scuttle Trade Boon', 20 April 2015, http://www. bdlive.co.za/business/trade/2015/04/20/chicken-dispute-unlikely-to-scuttle-trade-boon.

— (2015b), 'SA Should Embrace AGOA, Not Keep Its Distance', 7/05/2015, https://www.africanewshub.com/news/3067785-letter-from-washington-sa-should-embrace-agoa-not-keep-its-distance.

— (2015c), 'US Must Utilize Tools in AGOA to Pressure SA', 15 May 2015, http://www.bdlive.co.za/ business/trade/2015/05/15/us-must-utilise-tools-in-agoa-to-pressure-sa.

— (2015d), 'SA-US Agreement on Trade Deal Is Close. Obama Gives 60-Day Warning on Export Tariffs', 7 November 2015.

Business Report (2015a), 'US Lawmakers Up AGOA Ante: Thirteen Senators to Write to Davies, Blast SA Poultry Body', 1 April 2015.

(2015b), 'SA on Track to Resume Imports of US Poultry', 8 November 2015, http://www.iol.co.za/ business/news/sa-looks-to-resume-us-poultry-imports-1942246.

_ (2016), 'AGOA Deal Saved by the Bell', 8 January 2016, http:/www.iol.co.za/business/news/agoasaved-at-last-minute-1968091.

Davies, R. (2015), 'The Paris deal on Poultry: Implications for South Africa's access to the US under AGOA: Statement by Minister of Trade and Industry Rob Davies, in the National Assembly', 17 June 2015, http://www.gov.za/speeches/avies-statement-paris-deal-poultry-following-agoa-17-jun2015-0000.

— (2016), 'Update on AGOA Negotiations', speech to the National Assembly, Parliament of South Africa, 7 January 2016, http://www.gov.za/speeches/minister-rob-davies-update-agoa-negotiations-7-jan-2016-0000. 
Deloitte \& Touche (2013), 'Deloitte on Africa: The Rise and Rise of the African Middle Class', http://www. deloitte.com/assets/Dcom-India/Local\%20Assets/Documents/Africa/Deloitte_on_Africa-\%281\% 29_rise_and_rise.pdf.

Economist, 'Africa - the Hopeless Continent', 13 May 2000.

International Centre for Trade and Sustainable Development (ICTSD) (2015), 'US Senators Introduce Amendment to Enter Reciprocal Trade with African Countries', 27 May 2015, http://www.ictsd.org/ bridges-news/bridges-africa/news/us-senators-introduce-amendment-to-enter-reciprocal-trade-with.

Inside US Trade (2015), 'Inhofe, Coons Introduce African Free Trade Initiative Act', 19 May 2015, http:// www.inhofe.senate.gov/newsroom/press-releases/inhofe-coons-introduce-african-free-trade-initiative-act.

Kock, K. (1969), International Trade Policy and the GATT 1947-1967, Stockholm: Almqvist \& Wiksell. Law360 (2016), 'Obama Withdraws Suspension of AGOA Threat for South Africa', 15 March 2016, http://www.law360.com/articles/771902/obama-withdraws-agoa-suspension-threat-for-s-africa.

Meltzer, J. P. (2015), Reforming the African Growth and Opportunity Act to Grow Agriculture Trade, Africa Growth Initiative, March 2015, Washington, DC: Brookings Institute.

Mail \& Guardian (2016), 'Falling Rand Rains on AGOA Parade', 8-14 January 2016, http://mg.co.za/ article/2016-01-07-falling-rand-rains-on-agoa-parade.

News Ghana (2016),'US and South Africa Finalize Trade Discussions', 3 March 2016, https://www.newsghana.com.gh/us-and-south-africa-finalize-trade-discussions/.

Pigman, G. A. (2016), 'AGOA IV and the future of US-Africa Trade Relations', Commonwealth Hot Topics, Issue 127, March 2016, http:/www.thecommonwealth-ilibrary.org/commonwealth/ imprints/2016.

Politico (2016), Morning Trade, 11 May 2016, http:/www.politico.com/tipsheets/morning-trade/2016/05/ froman-heads-to-rwanda-hatch-cant-get-no-satisfaction-eu-commissioner-undeniable-china-is-notmarket-economy-214241.

Schneidman, W. (2015), 2015: A Pivotal Year for Obama's Africa Legacy, Africa Growth Initiative, Foresight Africa Series, Washington, DC: Brookings Institute.

Scheidman, W. and Z. Lewis (2012), The African Growth and Opportunity Act (AGOA): Looking Back, Looking Forward, June 2012, Africa Growth Initiative Publications, Number 7 of 43, Washington, DC: Brookings Institute, http://www.brookings.edu/research/reports/2012/06/agoa.

Toye, J. and R. Toye (2004), The UN and Global Political Economy: Trade, Finance, and Development, Bloomington: Indiana University Press.

United Nations Conference on Trade and Development (UNCTAD) (2006), 'Trade and Development Report', United Nations, Geneva.

United States International Trade Commission (USITC) (2014), 'AGOA Trade and Investment Performance Overview', April, https://www.usitc.gov/publications/332/pub4461.pdf.

US Congress (2015), 'Trade Preferences Extension Act of 2015', HR-1295, https://www.congress.gov/bill/ 114th-congress/house-bill/1295/text/pl.

United States Trade Representative (USTR) (2016), 'Remarks by Ambassador Froman and the Beyond AGOA Hearing', 28 January 2016, https:/ustr.gov/about-us/policy-offices/press-office/speechestranscripts/2016/January/Remarks-Ambassador-Froman-Beyond-AGOA-Hearing.

US Federal Register (2015), 'African Growth and Opportunity Act: Notice of Initiation of an Out-of-Cycle Review of South Africa Eligibility for Benefits - Scheduling of Hearing, and Request for Public Comments', https://www.regulations.gov/\#!documentDetail;D=USTR-2015-0009-0020https://www. federalregister.gov/articles/2015/07/21/2015-17772/african-growth-and-opportunity-act-noticeof-initiation-of-an-out-of-cycle-review-of-south-africa.

Wilkinson, R. (2014), What's Wrong with the WTO and How to Fix It? New Jersey: Wiley.

Williams, B. (2015), 'African Growth and Opportunity Act (AGOA): Background and Reauthorization', Congressional Research Service, 22 April 2015. 